\section{Loonie toonies}

I read Kaleidoscope's offering of Canadian Slang (ET45, Jan 96) with the bemused fascination that a native speaker always brings to such lists. I saw some old favourites ("pogey" and "Hollywood stop") and learned a few ones ("winter mole" and "gotchie-pull"). However, I particularly enjoyed the reference to "loonie" (our $\$ 1$ coin, with a loon on one side), because $E T$ arrived the very day that Ottawa issued the new $\$ 2$ coin - a bimetal offering, with a bear on one side of the inner circle. The week prior to its appearance, newspapers' letters pages had carried spirited correspondence about what to call this coin, with "twonie/toonie," "bearbuck" and "dubloon" the clear favourites. Then the coins were issued and, to the Mint's embarrassment and the media's delight, one of them promptly broke into its constituent parts. Three new names hit the suggestion list: "splittoon," "two bits" and "Q" - in honour of Quebec, its proposer helpfully explained, which also wants to separate. P.S. For those who care, "toonie" appears to be the winner.

Now a question for Dale Roberts. When a word is used by all (except a few po-faced Mint officials), and in all circumstances, is it still slang? Or does universality confer some slightly higher status?

Penny Williams,

Toronto, Ontario, Canada

\section{Cryptic crosswords and kilometres}

I was surprised and delighted to receive the Cambridge International Dictionary of English. Thank you so much. I had quite forgotten about completing and sending in the solution to the
Crossword from ET43. I have every issue of English Today from the start of publication. Looking through them, I find that I have tackled roughly half of the Crosswords, solved five, and submitted one solution several years ago.

Cryptic crosswords are not as popular here as in Britain. As far as I am aware, only the (Toronto) Globe and Mail publishes a daily cryptic. Only a few of my friends are addicted. I tell the rest that one does not have to be crazy to do cryptics - but that it helps!

My interest in language began at an early age. Part of my childhood was spent with immigrant Icelandic grandparents and with an aunt and uncle, all of whom still spoke mostly Icelandic in the home. My aunt taught me to read Icelandic from the Bible (a skill I was later to use out loud for many an hour after my grandmother went blind) and English from 'The Boys' Own Annual" and the dictionary.

My service in the R.C.A.F. during WWII took me to England (and also to Stalag Luft III in Germany), where I was first introduced to cryptic crosswords. My favourite is still the Daily Telegraph cryptic, probably because I can usually solve it within the hour. I am always delighted when I beat my British friends at what is essentially their game.

CIDE implies that the British pronounce "kilometre" with the accent on the first syllable, and that the Americans pronounce it with the accent on the second syllable. I have yet to meet an Englishman or Scotsman who places the accent on the first syllable. In fact my British friends laugh at my quaint pronunciation. The same is true for Americans, and most Canadians. But I am happy to say that most C.B.C. announcers say "KILometre", (not "kiLOmetre").
Again, thank you for my lovely surprise. I look forward to becoming familiar with it.

\section{Ed Eggertson, Burlington,Ontario, Canada}

\section{Crow-scaring jargon}

In Mark English's article in ET45 (Jan 96), among his listed examples of crow-scarer words I was interested to note jack-o'-lent, reported from Dorset, as I had hitherto met this word only in connection with Jack-in-theGreen and not with scarecrows. I have taken the following points from an article in English Dance and Song, Vol. XII, No. 5, November 1948.

1 Versions of the name/concept include: Jack-o'-lent, Jack a Lent, Jake of Lent, Jack-in-theGreen, The Green, The Green Man; and there may be links with Robin Hood, Robin-of-theWood. Similar ideas are known in Germany.

2 In 1553, a Mummers' Play Jake of Lent was performed in Aldgate.

3 There was a Country Dance Tune of 1650 named Jack a Lent. 4 Charles Dickens in Sketches by Boz mentions a May Day Chimney Sweeps' procession of 1836 in Somers Town and Camden Town, in which Jack-a-Lent took part. It had elements of Morris dance, mummers' play, maypole dancing, the Lord of Misrule and his Lady. Some Morris dancers today, notably the Bacup Coconut Dancers, black their faces to disguise their identity; there may be a connection here with the black of sweeps' faces.

5 Ben Jonson mentions a puppet of straw called Jack of Lent set up as a cockshy on Hampstead Heath in Lent and burnt on Palm Sunday/Monday to save the crops; Jack Straw's Castle still exists as a reminder. The words Jack-straw and jackstraw 
mean a straw effigy. (Also, a possible link with guy and the burning of Guy Fawkes?)

6 There are still in England many traditions of a Jack-in-theGreen figure: that is, a man inside a framework covered with greenery led in procession through the village/town in early Spring to ensure good crops.

Two probable coincidences: (1) the word tatterdemalion (a ragged man) looks superficially similar to the tattie-bogie/tatiebogle group, but tatter = rag and tattie = potato are presumably unrelated; (2) the word jack-o'lantern (hollowed-out turnip for Halloween) is like the jack-a-lent group, but again a connection is unlikely. But could there have been an association in the public mind? I am wondering if perhaps a scarecrow was originally put in the fields not dressed in the farmer's old clothes and actually to scare the birds but as a celebratory figure to ward off evil spirits' and ensure fertility and a good harvest.

(Incidentally, I note the inclusion of hodmandod, which I have heard of only with the meaning of 'snail'; here I really cannot see a connection! - though dud and dud-man contain a similar element.)

I hope readers will find these points of interest.

(Mrs) Juliet Bending St Albans, Hertfordshire, England

\section{down with capital letters}

I am writing to let you know that we the foreign learners of English usually encounter with a problem when learning the language. You must aware that two kinds of letters are commonly used in English - small letter \& Capital letter: But all learners have to master in both letters. If you look to the Capital letter, you will see that they are the repetition of small letter and they waste a lot of time of a learner. Besides, they have no use in spoken English. I think English language can be expressed without capital letters and no great change in meaning will take place if they are removed from English language. Moreover, to learn the uses of Capital letter in various situation snatch away the time and sometime puzzle the learners.

So, my suggestion \& request to all Britisher that they will take initiative to remove Capital letter from English inorder to make it more easier to the learners \& less weight in letter. What do you think?

\section{A. Taher, Sodia Bazar, Dist. Comilla, Bangladesh}

\section{Njuu Ingliq}

The item Donald MacQueen sent you (ET45) reminded me of $\mathrm{my}$ 'Nyuu Ingliq' which appeared in Scanorama (SAS in-flight magazine) in October 89, and before that in a slightly different version in my own (modest!) English Magazine, autumn 84. I enclose a copy: see panel p.63.

It was inspired by memories of a similar article I had enjoyed years before in a children's Reader's Digest anthology (from the $50 \mathrm{~s}$ or $60 \mathrm{~s})$. I wanted to share it with my students but was unable to trace it, and so I was forced to invent a similar scheme. The original also introduced the changes into the text as they were presented and, as I remember, suggested the use of 'c' for 'th'.

My article has been reprinted in the Matsol Newsletter and Health Care for Women International, but I hardly think it will have made its way to Poland from either source! Perhaps the writer of the original article was from Poland? Or perhaps someone flew SAS to Poland in 89 ? Interesting!

Pat Revill, Halmstad, Sweden
A World Style Council and English spelling

Only connect! Two events in January 96 , one small and one large, cry out to be connected, so that the small one may eventually overtake the large in longterm importance.

The small one is Tom McArthur's daring, yet oh so tentatively worded, question at the end of his ET45 editorial, whose last paragraph says:

“... alone among Anglophone territories Australia holds an annual Style Council, to discuss its standard usage. What if one day the whole world of English copied that idea?"

The large event is that German has at last committed itself, by international agreement, to a significant modernization of its spelling - for the first time in nearly a century. From August 1998 children will be taught the new spellings, though the old ones will not be considered wrong until the year 2005 . If it took some years to hammer out the details and get the necessary political support for this spelling reform, one of its consequences will be the setting up of machinery (an 'Interstate Commission') to keep German spelling under continuous review and introduce future reforms more expeditiously.

At least the following other languages have modernized their writing systems this century: Afrikaans, Chinese, Danish, Dutch, French, Greek, Indonesian/Malay, Irish, Japanese, Malayalam, Norwegian, Portuguese, Romanian, Russian, Spanish, Turkish. No doubt ET readers can add further names to this list.

Why has German taken this step? To improve literacy, "im Interesse der Schule" (= for educational reasons), to make the written language "easier to learn and easier to use." What criteria were applied? The new spellings 


\section{A modest proposal for simplifying English spelling}

The following is the text of Pat Revill's article 'Njuu Ingliq' as it appeared in Scanorama, Oct 89.

For the last 13 years I have been teaching English to Swedes, a logical, rational people, for whom every problem has a solution. In the case of the English language the problem is the spelling.

In vain I try to explain about William Caxton, the first English printer, who in 1477 began to fix the language on the printed page before a consensus had been reached about how to spell it.

I proudly mention the centuries of British and world history that are reflected in English spelling. I even try to point out that countless attempts at reforming English spelling have been made in the past and that none of them ever worked. And I tell people that in any case you'd never get a single spelling system that catered for all the different varieties of world English.

They're having none of it. When spelling gets too complicated you simplify it. It's as simple as that. Sweden did it at the turn of the century and so can "Tatcher's England" now. It's just typical English conservatism that prevents Britain from making the written language more accessible to foreigners.

Well I mean. You can't take that lying down, can you? And maybe the objectors do have a point: learning to spell their own language is no picnic for English-speaking people either. So here, for all of us, native and non-native speakers alike, I am proud to present:

A quick look at the English alphabet,ab(c)defghijklmnop (q)rstuvw(x)yz shows that 3 letters are unnecessary:

"c" can be replaced by " $\mathrm{s}$ " or "k";

" $q$ " can be replaced by " $k w$ "; " $\mathrm{x}$ " can be replaced by "ks" or " $k z$ " or even " $\mathrm{z}$ " depending on the word it is in.

This means that these 3 ekstra letters kan now do kompletely new jobs and it is kwite klear which letters they should replase:

"c" kan take the plase of the "ch" sound;

"q" kan take the plase of the

"sh" sound; and

" $x$ " kan take the plase of the "th" sound (box of xem).

Xis may look a little konfusing at first but I am kwite qure xat after a bit of praktise it will bekome muc easier. Cildren, of kourse, will have no diffikulty in learning xe new mexod at skool. We adults will have televiqon programmes to teac us.

But don't xink xat xat is all xere is to it. We haven't finiqed yet: in fakt, we have only just started improving Ingliq spelling. Double konsonants are unesesary. Xey kan go. So kan leters xat ar not pronounsd.

We must get yust to yuzing $x$ aktyual sowndz xat we hear. And we must look karfuli at $x$ hole kwescun ov vowelz. I sujest xat xay kan be divided into xree grewps.

1. In xis grewp you hav $\mathrm{x}$ qort vowel sowndz, wic we rite

$$
\begin{aligned}
& \text { "a" az in "pat" } \\
& \text { "e" az in "pet" } \\
& \text { "i" az in "pit" } \\
& \text { "o" az in "pot" } \\
& \text { "u" az in "put" or "kup" (cup) }
\end{aligned}
$$

2. $X$ sekund grewp haz $x$ long vowel sowndz: xat $i z, x$ wunz xat sownd like $\mathrm{x}$ standd Britiq Ingliq pronunsiayqun ov $x$ letuz. Xay wil bee ritn wix dubl letuz.

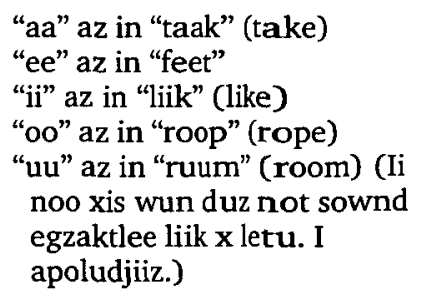

Wot u graat impruuvment xis iz! See how lojikl $x$ sistm iz beekuming!

3. $X$ vowelz in $x$ fiinl gruup ar not soo komn and soo wee kan riit xem wix an aksent and not spoyl $x$ luk ov $x$ paaj:

"â" az in "hât" (heart)

"ê" az in "dêr" (dare)

"i" az in "ff" (fear)

"ô" az in "bôt" (bought)

"û" az in "wûd" (word)

Fiinulee, lets uboliq $x$ upostrufee, wic noowun undustandz eneewaa, and xats it! Simpl, iznt it!

Let $x$ flagz bee raazd ôl oovu $\mathrm{x}$ wûld! Nyuu Ingliq speling haz kum tuu saav us ôl! See hw muc eeziu liif iz wen yuu reqnuliiz Ingliq speling!

What do you mean, you prefer it as it is? were designed for "cautious simplification" and "elimination of exceptions and peculiarities", to "make the basic rules more widely applicable and enhance systematicity." Were any constraints observed? The "orthographic tradition was to be maintained", "texts using the old spelling were not to be harder to read".

So what's the connection?

English spelling is a problem which manifests itself wherever written English is taught (i.e., worldwide). Attempts to enunciate rules for English spelling typi- cally end up spending more time on exceptions (and sometimes exceptions to the exceptions) than on the rule itself. English teachers have never been able to agree how (or, more recently, whether) to teach spelling. Politicians blame the rising generation, 
or teachers, or opposing parties, for disastrous (and allegedly declining) literacy standards. Misspellings proliferate in public as well as in private places. Nonnative speakers constantly mispronounce words by taking the spelling as their guide. Dictionaries list hundreds (thousands?) of alternative forms, about which America and Britain often disagree, with Canada and Australia hovering uneasily between. Unlike most alphabet-based languages, English scarcely gives a thought to the alphabetic principle that spelling needs to reflect pronunciation. When the respective merits of the alternative ISE/-IZE endings are debated, the crucial point is rarely mentioned that -IZE better represents the sound. A recent NATO-chief thinks practise rhymes with baptise - and who can blame him?

Outside observers readily describe English spelling in terms such as 'one of the world's most awesome messes' (an Italian view) or 'an insult to human intelligence' (a German view). But to judge from what the English language professionals have to say most of the time, one would hardly guess there was anything seriously wrong: usually, spelling is at best only marginally on their agenda. Why isn't it at the top of all our agendas?

Spelling, as Pam Peters makes clear in ET45, is one of the subjects that raises its head at Australian Style Councils. Yet within the framework of World English, there is little more that such a regional body can do than vacillate between conflicting American and British preferences. It does not innovate - how, after all, could Australia launch its spelling off in an independent direction from the rest of the world? The (relative) unity of English spelling around the world today is its redeeming feature.

Yet there are stirrings of impatience with today's spelling which might yet trigger disintegration of the world standard. A proposal called LOJIKON, currently being propagated in India, advocates the benefits of the LOJKal (i.e., consistent) spelling of KONsonants in English, especially for non-native speaking learners. Is it conceivable that this massive constituency might decide to shake off the (historically colonial) orthographic yoke, and reshape the system to meet its own peda- gogical needs, in defiance of the Anglo-American tradition? And if that happened: who would be the greater losers, the innovators or the traditionalists?

Tom McArthur's idea for a world Style Council for the first time suggests an organizational framework where the issue of English spelling as a world problem could be addressed. At present, only the Simplified Spelling Society, with its various associates in other countries, is seriously considering the question at all; but its resources do not stretch to major worldwide initiatives. it faces a wall of scepticism from people who say, "Well, reforming English spelling may be splendid in theory, but we don't see how the world can possibly be got to move as one."

Would ET readers agree that, by making the connection between the German Interstate Commission, the Australian Style Council, and Tom McArthur's editorial, we may sow the seed for something previously barely imaginable, yet centuries overdue?

Chris Upward, Simplified Spelling Society, 61 Valentine Road, Birmingham B14 7AJ, England

\section{CROSSWORLD}

\section{ETT 46 Solution}

\begin{tabular}{|c|c|c|c|c|c|c|c|c|c|c|c|c|c|c|}
\hline 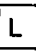 & 1 & $\mathbf{P}$ & $\mathbf{S}$ & $T$ & 1 & $\mathrm{C}$ & K & & $\mathbf{N}$ & 1 & $\mathbf{M}$ & $\mathrm{B}$ & U & $S$ \\
\hline I & & A & & $E$ & & 0 & & D & & $\mathbf{N}$ & & $\mathbf{L}$ & & L \\
\hline B & $A$ & $\mathbf{R}$ & 0 & $\mathbf{N}$ & & "в & R & 1 & $E$ & $F$ & $\mathrm{C}$ & $A$ & S & $E$ \\
\hline 1 & & A & & 0 & & B & & A & & I & & $S$ & & $\mathbf{N}$ \\
\hline${ }^{12} \mathrm{~T}$ & $\mathbf{u}$ & $M$ & B & $R$ & 1 & $L$ & & D & $\mathbf{E}$ & $\mathbf{N}$ & 0 & $\mathbf{T}$ & $E$ & D \\
\hline U & & $E$ & & & & $E$ & & $E$ & & I & & & & $E$ \\
\hline$M$ & I & $T$ & $E$ & ${ }^{15} \mathrm{~S}$ & & $\mathrm{R}$ & $E$ & $\mathbf{M}$ & & ${ }^{17} \mathrm{~T}$ & 0 & ${ }^{18} \mathrm{P}$ & $E$ & R \\
\hline & & $E$ & & $T$ & & & & & & $\mathbf{u}$ & & R & & \\
\hline $\mathbf{N}$ & $E$ & R & $v$ & $E$ & & $\mathrm{C}$ & 0 & $\mathrm{C}$ & & ${ }^{22} M$ & $A$ & 0 & $\mathrm{R}$ & ${ }^{23} 1$ \\
\hline A & & & & $E$ & & $E$ & & 0 & & & & $\mathbf{L}$ & & $\mathbf{N}$ \\
\hline$u$ & $\mathrm{~T}$ & ${ }^{25} \mathrm{~T}$ & $\mathbf{E}$ & $\mathbf{R}$ & $E$ & $\mathbf{R}$ & & ${ }^{8} \mathrm{R}$ & A & ${ }^{27} \mathrm{P}$ & $\mathbf{P}$ & 0 & R & $T$ \\
\hline 5 & & W & & S & & $E$ & & $\mathbf{N}$ & & 1 & & $N$ & & $E$ \\
\hline${ }^{20} \mathrm{E}$ & $\mathbf{N}$ & 1 & $\mathbf{G}$ & $M$ & A & $\mathbf{T}$ & 1 & C & & ${ }^{20} \mathrm{~L}$ & A & $\mathbf{G}$ & E & R \\
\hline A & & $\mathrm{s}$ & & A & & 0 & & 0 & & A & & $E$ & & 1 \\
\hline${ }^{80} \mathrm{M}$ & $\mathrm{U}$ & $\mathbf{T}$ & A & $\mathbf{N}$ & $\mathrm{T}$ & & $A$ & B & $s$ & $\mathrm{U}$ & R & D & $u$ & $M$ \\
\hline
\end{tabular}

\section{ET 45 Crossworld winners}

The winners of the Collins Dictionary of Quotations, eds. A. Norman Jeffares \& Martin Gray, 1995, the prize for our October 1995 crossword, are:

John Edwards, Psychology Dept., St. Xavier University, Antigonish, Nova Scotia, Canada Laurie Donaldson, Muswell Hill, London, England Kelly Hayden, Iowa City, Iowa, USA

Mrs Valerie High, Braughing Friars, Ware, Hertfordshire, England

Mrs J. Nelson, Troston, Bury St Edmunds, Suffolk, England

Note We apologise for reversing the prizes for ETs 44 and 45 , and hope that receiving a misassigned prize will not detract from the pleasure of winning the book. All ET prizes are selected for their excellence. 